\title{
Place Making, Mega Events and Ritual Effervescence: A Case Study of the Nelson Mandela Concert in Tromsø, 11th June 2005
}

\author{
SIV ELLEN KRAFT \\ University of Tromsø, Norway
}

\begin{abstract}
Based on local newspaper coverage of a Mandela solidarity concert in Tromsø in June 2005, the article discusses the importance of mega events in relation to place construction, with particular emphasis on ritual aspects. Mega events are shaped by a global discourse, which emphasizes the uniqueness of place and locality. Through the staging of mega events, people are provided with opportunities for thinking about themselves and their locality, for experiencing the pictures and messages presented, and for representing them to the world. Such opportunities are not limited to mega places and centres of the world order. This was the case of a mega event in a small place, and a place, moreover, that has traditionally been designated the primitive backyard of the Norwegian periphery. The concert stories drew upon such established images, but revised them as indicative of uniqueness and authenticity. Constructed in contrast to world centres in general and 'Norwegian-ness' in particular, the concert stories at the same time spoke to the emergent features of a global civil religion. Placed under the midnight sun in northern Norway, Mandela served both as a high priest of this project, and as the bridge between local uniqueness and 'good' globalization.
\end{abstract}

Keywords: Mega events, Nelson Mandela, place, rituals, Norway, local and global

This article deals with local place construction in the context of a ritual media event. The event was a solidarity concert, co-hosted with the International Nelson Mandela Foundation and dedicated to the war against HIV/AIDS. ${ }^{1}$ It took place in Tromsø, the regional centre of northern Norway, and was presented in newspapers as extraordinary and historic. Adding to the gen-

${ }^{1}$ The concert was titled 46664 Arctic. 46664 was Mandela's number during imprisonment. 
eral effervescence created, Mandela told his concert audience that 'tonight you have become Africans':

During the last week you have demonstrated to the world your humanity and compassion [...] In recognition of this leadership, we have made Tromsø the first ambassador city of the 46664. Many years ago I said that my long march had not yet ended. Standing here tonight it gives me great pleasure to know that we are not alone. By accepting the challenge you have become part of us, so that you are now Africans. (Nordlys 13.06.05, 14.)

The international press contributed to framing, marking and adding importance to the concert. However, local newspapers were the main sites of identity discourse in connection with the event, and therefore represent my main sources. It is unlikely that many northern Norwegians followed South African or British media coverage of the concert, but quite likely that they read about such coverage in local newspapers. The concert was a main topic of both Bladet Tromsø and Nordlys during the summer of 2005. By focusing in detail on the event, they helped portray it as historical and extraordinary, and as such they contributed to processes of meaning making and meaning consolidation.

Intended as a framework for my analysis, the article starts with a discussion of ritual theory and the relationship between the global and the local - between mega events as civil rituals and the emergent features of a global civil religion. This is followed by introductory comments on the local setting - the city of Tromsø and issues relevant to the following analysis. Finally, my analysis of local newspaper coverage is organized according to four main motives, each of which figures prominently in the source material.

\section{Ritual Aspects}

'Ritual' is not a universal category. What appears to be universal, however, is the 'setting apart' of certain activities as particularly important and unusually effective (Bell 1997). In order to frame such aspects I draw upon elements from performance theory ${ }^{2}$, a broad field of overlapping approaches, concerned mainly with the issue of how rituals work; in what their power consists, and how emotive, physical and sensual aspects contribute to this power (ibid., 73). The following section relates mega events to the category of civil rituals and processes of globalisation. No longer exclusive to the

\footnotetext{
${ }^{2}$ The performance approach to ritual studies dates back to the 1970s and the coming together of several different contributions, including Victor Turner's description of ritual as 'social drama', Austin's theory of performative utterances, Kenneth Burke's discussion of dramatism, and Erving Goffman's work (Bell 1997, 73).
} 
national context, mega events also - and in this case primarily - draw upon the level of global images, icons and values.

\section{Ritual Performance}

Performance theorists accept the Durkheimean notion of ritual as characterized by effervescence, and such effervescence as crucial to the moulding of individuals and societies. But effervescence is not related to a general rule of functionalism. Rituals can be more or less successful according to the perspectives of performance theory. They do not simply reflect pre-existing landscapes, but actively construct reality and effectively contribute to changes in values and ideas (Bell 1997).

Exactly how this is achieved is a matter of much debate, but certain analytical concepts have been established as basic, among these what I in the following refer to as 'framing', 'display', 'public reflection' and 'multi-sensory appeal' ${ }^{3}$ Framing, first, has to do with the 'setting apart' of certain activities. Through framing certain activities or messages 'set up an interpretive framework within which to understand other subsequent or simultaneous acts or messages' (Bell 1997, 74). In the case of the concert, newspapers in important ways contributed to these processes. In addition, the week preceding the concert saw a host of related activities, an unusually high number of tourists and visitors, and an extensive reorganizing of the city surface including huge Mandela posters, concert programs, ticket booths and souvenirs.

Thus prepared for an extraordinary event, 18000 people gathered in Tromsdalen on the night of the concert. 18000 people is a large gathering by any account; for a city of 62000 inhabitants - it's huge. This was a mega event in a small place, a place which had never hosted anything of this magnitude, and whose population was very much conscious of the world watching. In the language of performance theory the concert was an occasion for ritual display, and ritual display may be expected to serve at least two tasks. On the one hand it contributes to a sense of awe and overwhelming, in this case related to size and spectacle. On the other hand display - as a way of doing (rather than merely saying) - demonstrates the power, stories or messages presented, thereby providing them with factual status (Rappaport 1999, 56).

Public reflection may be related to the otherness of liminal times or places. Extraordinary events - by the fact of being extraordinary - present

\footnotetext{
${ }^{3}$ See Bell 1997 for a more elaborate presentation of these.
} 
themselves as a break from routine. In this way they may help create a distance necessary for reflection to take place, and 'live' material for the mind to ponder upon. The presence of the press may further encourage such distancing. Newspapers and television quite literally enable crowds to become audiences to themselves, to view themselves from outside and - in the case of mega events - to do so in the company of thousands, if not millions of distant viewers.

Rituals communicate on several levels simultaneously, in this case involving hearing, seeing, smelling and bodily movement. In order to make sense of this dimension, some scholars have appealed to kinaesthesia (the sensations experienced by the body in movement); others to synesthesia (the evocation of overwhelming sensory experiences) (Bell 1997, 74). As an example of such advances, social anthropologist Roy Rappaport has argued that the achievement of special states of mind is largely the outcome of ritual's peculiar temporal characteristics, and that dance is a particularly effective medium of such changes: 'In dancing the whole body enters into the computations of the prevailing consciousness, this at the same time that the individual's sense of his or her separation from others is submerged or overwhelmed as a function of continuous, tight coordination with them' (Rappaport 1999, 221).

Dance and music, then, may induce feelings of wholeness and belonging, or create the premises for such feelings to emerge. And this may partly be related to the imposing upon social interaction of special tempos - 'tempos which may be difficult to achieve under mundane circumstances or that are inappropriate to all but a very few ordinary activities' (Rappaport 1999, 221).

\section{Mega Events as Civil Rituals}

Specific historical settings tend to produce similar patterns and types of ritualisation, as well as more or less common perceptions of what rituals are. In late modern western societies a dual tendency has emerged: an extensive privatisation of ritual on the one hand and, on the other hand, a vast body of vaguely religious 'civil rituals', such as pledging allegiance to the flag and swearing in political leaders (Bell 1997). Civil rituals typically have little of the formalism, traditionalism and invariance typical of western rituals in the near religious past. They emphasize moral and ethical commands over ritual duties, and their sacred symbolism tends to be implicit or ambiguous (Bell 1997, 201). As such they provide room for the heterogeneous 'congregations' of late modern society, and religion placed outside the boundaries of organized religions. 
Robert Bellah's 'Civil religion in America' (Bellah 1967) is the seminal study in connection with civil rituals. In line with his work, most contributors have related civil rituals to the national context, with civil rituals as expressions of civil religions, which in turn consist of important national ideas and values. Mega events have similarly been related to the national framework as 'important to the story of a country, a people, a nation' (Roche $2000,6){ }^{4}$

In an article about Princess Diana, Roland Boer suggests an extension to this perspective. Civil religion has more recently moved on to the global level, he argues. As a global phenomenon civil religion 'has been creeping, perhaps a little more slowly than other dimensions of culture, into the global arena, particularly through a global media that is able to transmit and present iconic figures to a world-wide audience' (Boer 1997, 83).

Boer mentions Nelson Mandela, Mother Theresa and Princess Diana as examples of global icons, but does not further elaborate upon the globalisation of civil religion. Adding to his insights one might argue that the semi-sacred status of such figures speaks to the semi-sacred values of the world order, to core modern values such as liberty, equality and fraternity (the ideals of the French Revolution), and to more recent additions such as pluralism and environmentalism. ${ }^{5}$ These same values are crucial to global institutions, such as the UN and human rights, and mega events are venues for expressing them. ${ }^{6}$ Mega events invariably relate to core modern values. The alternative, although hypothetically possible, is not realistic. It is, for instance, hard to imagine an Olympic ceremony constructed upon ideals of a homogenous society, the defence of national boundaries and racial purity of the host population.

Mega events, then, may be related to the emergent features of a global civil religion. Nation states frequently serve as the local counterpart of such interaction, ${ }^{7}$ but this setting also allows for alternative routes. The Mandela

\footnotetext{
${ }^{4}$ Roche mentions Nelson Mandela's willingness to support and participate in mega events (including South Africa's bid for the 2006 World Cup and the 2008 Olympics) as proof of their importance: 'the fact that a politician of his stature would choose to continue to serve his vision of his nation by being involved in such bids speaks eloquently for the importance of mega events for nations in terms of their self-image and place in the world society' (Roche 2000, preface).

${ }^{5}$ For a further discussion of core modern values, see Beyer 1994, 101.

${ }^{6}$ In scholarly literature the category of 'global events' includes both unexpected events (such as the death of Princess Diana and Mandela's release from prison), and planned events, such as Olympic Games and certain types of solidarity concerts.

${ }^{7}$ Olympic Games tend to focus on the nation in relation to the global, but to some extent this may be related to organizational matters. Bidding cities need the support of the nation (economically and in relation to the international IOC). Also, the IOC treats bidding cities as representatives of their nation.
} 
concert, I will argue in this article, was not related to Norway and Norwegian-ness. Emphasis was placed on Tromsø's place on the world map - on locality in relation to the global level.

\section{The Local Setting}

Mega events do not merely reflect established stories and realities. They contribute to the construction of locality, and in recent times such arrangements usually include an element of conscious image building. ${ }^{8}$ In the case of Tromsø, a discrepancy between established stereotypes and actual conditions was probably important. Northern Norway has traditionally been constructed according to a north-south axis. According to this view, south is where power is situated and fortunes decided. North is the exploited and suppressed backyard of Norway - a neglected region, left out of the national project and treated as a kind of colony (Guneriussen 2005, 2).

Related to this perspective of subordination and victimization, the people of the north have been constructed through what may be referred to as a primitivist discourse. ${ }^{9}$ Primitivism comes in a positive (or romantic) and a negative version, based primarily on a common pool of images but interpreted differently. Both, moreover, are constructed in contrast to a presumed modern, western, or in this case Norwegian identity. (Geertz 2004.) Still common in mass media portraits of northern Norwegians, ${ }^{10}$ primitivism emphasises smallness, periphery, nature and tradition. Northern Norwegians are nature-people; living in close contact with nature and moulded by rough, dramatic and spectacular landscapes. In order to survive in this situation, they have developed strength and roughness, willpower and a sense of humour. Like primitives of all kinds they live in close-knit villages, characterized by solidarity and community, and in line with these pre-modern conditions people tend to be simple and somewhat naive.

In recent years such stereotypes have been confronted and questioned. There is, critics argue, a need for 'new stories' to be formulated - stories more apt to the present situation of northern Norwegians, and particularly to the 'cosmopolitan' population of Tromsø. ${ }^{11}$ The regional centre of northern

\footnotetext{
${ }^{8}$ Roche mentions South Africa as an example of a governmental attempt at changing national political identity through the hosting of global mega events (Roche 2000). More generally, tourism is usually an element in such branding or image building.

${ }^{9}$ For a study of perceptions of Northern Norway and northern Norwegians, see Drivenes \& Hauan \& Wold 1994.

${ }^{10}$ Television comedies have been particularly rich sources of such stereotypes, including the northern Norwegian 'Arthur Arntzen', and the more recent 'Team Antonsen'.

${ }^{11}$ Since the end of the 1990s, the issue of place identity has been an important topic in newspaper debates. Also, during the spring of 2003, several public seminars dealt with this issue (Paulgaard 2006).
} 
Norway, Tromsø has 62000 inhabitants. It is the largest city north of the Arctic circle, and in terms of educational and cultural facilities it is by far the most developed. The northernmost university of the world is located here, along with a regional hospital and a polar research centre, and the city is known for a lively nightlife, including annual film and musical festivals. Adding to this 'metropolitan' character, modern day Tromsø hosts 120 nationalities, including ethnic Norwegians, Sami, Russians, Finns, and immigrants and refugees from around the world.

Late modern Tromsø, then, fits poorly with the established stereotypes of simple fishermen, daily fighting the forces of the wilderness. Probably inspired by such a discrepancy, two mega events have been proposed and debated during the last couple of years. Prior to the Mandela concert, a local committee developed a proposal for the 2014 Winter Olympics in Tromsø. Although rejected by the Norwegian government, the Olympic proposal in important ways paved the way for the Mandela concert, and it did so in at least two ways. First, the proposal appears to have lifted levels of ambition and sparked interest in mega events and the city's potential for hosting them. Second, the local planning committee provided a new, coherent and extremely ambitious conception of Tromsø and its potential. Olympic Games proposals imply conscious image making. In order to be competitive, proposals must create coherent stories of the place, that is, stories of what this particular place can offer and why its staging of an Olympic Games will be unique. Indicative of both the homogenizing and the differentiating forces of globalisation, these events are shaped by a global genre which emphasizes the uniqueness of place and locality (Urry 2003). As sociologist John Urry has put it:

[G]lobal mega-events such as the Olympics seem both to presuppose the emergence of local host cities and to reinforce their emergence. These are places chosen for their supposedly unique, local characteristics that make them especially appropriate for the hosting of what are increasingly global events. (Urry 2003, 86.)

The overarching ideals of 'Olympism' serve as the horizon of local uniqueness. In line with the idealistic origins of the Games, pursuit of world friendship and peace has usually been an ingredient in Olympic ceremonies (Roche 2000, 198). ${ }^{12}$ Derived from the enlightenment and nineteenth century progress worldviews, these universalistic and humanitarian values

\footnotetext{
${ }^{12}$ The modern Olympic Games were revived by the French baron Pierre de Coubertin in Athens in 1896. His expressed goal was to unite mankind through an international festival dedicated to athletic greatness (Chaffer \& Smith 2000, 2).
} 
have in recent times often been expressed in terms of human rights and environmentalism (ibid.).

True to this tradition, Tromsø's proposal presented a coherent story of local uniqueness and global commitments. And in doing so it drew selectively upon established stories of the place - exaggerating certain features, ignoring others and adding novel ingredients. Most notable is the global orientation and grandeur of visions, and within this perspective is Tromsø's importance as a city of peace. Tromsø University has a tradition for granting honorary doctorates to peace makers from around the world - the Dalai Lama, Desmond Tutu and Rigoberta Menchu all have received one. In addition, in 2000 the university founded a Master's programme in peace studies, and a peace research centre. In the proposal these small-scale institutions are elevated to the status of being able to improve the world. Tromsø is presented as a peace city, dedicated to 'the creation of a more peaceful and just world' and 'new goals and perspectives for environment, peace and development, locally, nationally and globally' (Tromsø 2014, Fact sheets: 2). Meanwhile, what the proposal refers to as 'arctic magic' caters for the uniqueness of the event, and perhaps also for its lofty visions of improving the world. Arctic magic, as we later shall see in more detail, has to do with the place and its 'spirit' - of dramatic wilderness and the strength of locals, of a potential lingering on the edges of Norway and the margins of civilization.

In relation to ongoing discourses on place uniqueness, the twin concept of peace and arctic magic served at least two tasks. On the one hand it tapped into a global discourse of peace making as an established priority and wilderness as a more or less ultimate value. On the other hand it contrasted Tromsø with Norway and Norwegian-ness. The stereotypical Norwegian landscape is 'the fjords' ${ }^{\prime 13}$ it is decisively not the arctic wilderness presented in the Olympic Game proposal. Meanwhile, the peace concept on one level communicated with recent formulations of Norway as a nation of peace, ${ }^{14}$ but in developing this perspective the proposal situated Troms $\varnothing$ in this position, thus replacing rather than extending national images. The proposal does not refer to nationally established and important peace centres, and generally has little to say about Norway and Norwegian-ness. To

\footnotetext{
${ }^{13}$ Cultures are formed in opposition to other cultures - to one or more 'others'. This, Macnaghten and Urry argue, 'applies equally to the spaces of landscape; that part of the appeal of one's particular countryside is the contrast that it exhibits to other landscapes'. (Macnaghten \& Urry 1998, 183.)

${ }^{14}$ Images of Norway as a peace making nation have primarily been developed in relation to the turn to so-called value diplomacy in Norwegian foreign politics. It implies, historian Hilde Henriksen Waage in a study of the Oslo process claims, a tendency to exaggerate national potential and take on responsibilities 'a couple of sizes too large'. Typical of such tendencies, the Oslo process added to a self-created myth of 'Norway as a kind nation, which stands on equal terms with both parts and gives to them food in a cosy atmosphere' (Dagbladet 26.04.04).
} 
the extent that it is mentioned at all, 'Norway' tends to be either subsumed under northern Norwegian images, or clothed in symbols so vague as to be meaningless. ${ }^{15}$

Newspaper coverage of the concert drew extensively upon the ideological scenarios here presented. And by actually taking place the concert provided life and solidity to visionary creativity. We have, thus, an element of dialogue between the Olympic proposal and the Mandela concert - between myth making and ritual display.

\section{The Mandela Concert - Themes and Issues}

A main event during the summer of 2005, the Mandela concert gathered extraordinary attention. For weeks this was the number one topic of local newspapers, dominating headlines and discussed in editorials, comments, interviews and letters.

In order to make sense of this material, I have selected four themes, referred to in the following as 'making history', 'the magic of Mandela', 'place spirit' and 'we are all Africans'. Themes have been chosen on account of their dominant position in the material, as well as for their relevance to place identity. In the language of discourse theory, I have been concerned with collocations - 'distinct patterns of co-occurrence between keywords and other words' (Fairclough 2003, 6). Referred to by some scholars as 'nodal points', the key words chosen are privileged signs that serve to organize discourse and grant meaning to other signs (Laclau and Mouffe 1985, 112).

\section{Making History}

On June 13th the front page of Nordlys summarized the concert as 'magic and historical'. According to its chief editor this was 'a night for history books', a night 'whose minutes will have a place in eternity'. 'Each and one of those present at the concert wrote history', and this was 'an important and beautiful history' (Nordlys 13.06.05). Adding international support to such interpretations, the director of the Nelson Mandela Foundation spoke of 'witnessing history' (Nordlys 13.06.05), and according to the chief editor of

\footnotetext{
${ }^{15}$ Indicative of this tendency, the opening page presents the Olympic concept as based on 'symbols important to Norway as a nation' (namely 'the arctic dimension, the peace dimension and culture and environment'), and values typical of 'town, region, coast and country' - namely 'authenticity' ('in the form of compassion, natural, honest and unpretentious'), 'generous' ('in the form of open, warm, hospitable and friendly'), 'courageous' ('in the form of creative, strong, explorative and persevering'), 'fun' ('in the form of humour, happiness and energy'), and 'contrasts' ('with mountains and oceans, pristine nature versus urban life, and warm people in a cold climate'). These values are identical with stereotypical images of northern Norwegian-ness. And the 'symbols' chosen are either marginal to current concepts of Norwegian-ness or lacking in substance. (Tromsø 2014.)
} 
Tromsø 20000 people had gathered for a common experience - 'an experience that three generations will talk about for years to come' (Tromsø 13.06.05).

Contributors agreed that something extraordinary had taken place - something worthy of remembrance and indicative of major changes. The concert, according to the stories presented, marked the beginning of a new era for Tromsø and its inhabitants, perhaps even for the world and global problems. Local enthusiast professor Ole D. Mjøs spoke of a demarcation line in the history of Tromsø, adding that he hoped 'it will also be a demarcation line in the fight against HIV/AIDS in the world' (Nordlys 9.06.05). The chief editor of Nordlys agreed that 'Tromsø is changed' and 'we have moved the world' (Nordlys 13.06.05), and journalist Linda Vaeng Sæbbe spoke of the forces released: 'We have made the impossible possible. It is too early to say what kind of forces this in turn may release. But that it will be grand and important of that I am certain.' (Nordlys 16.06.05.)

Along with the rhetoric of great change, the theme of 'doing the impossible' was an important element in newspaper coverage. This was a 'wild idea' turned into a success, and a success - as one headline phrased it - 'Against all odds' (Hanssen, Nordlys 18.06.05). Not only had the Norwegian government been less than supportive, also co-operation with international organizations proved frustrating and difficult. Recalling initial meetings with leaders of the Mandela Foundation, a member of the local organizing committee noted that they had not been taken seriously. 'A tiny dot in a remote place in a remote country', Tromsø was not the best of starting points for a gathering of international stars and worldwide attention (ibid.). Leader of the committee Anne Marit Bjørnflaten agreed that the process had been difficult. Describing her frustration at a meeting with several men from the Mandela Foundation and London's music industry, she notes that 'at this point they wanted to move the concert to Oslo [...] and to us that was the worst of all possible scenarios' (ibid.). Meanwhile, the Norwegian government rejected a plea for a state economic guarantee, despite enthusiastic lobbying, a personal letter to the prime minister from Nelson Mandela and a plea from archbishop Desmond Tutu. The concert was finally secured by the Norwegian Parliament, against the wishes of the government.

I have found only one reference to the importance of 'placing Norway on the map' in this material (editorial, Tromsø 13.06.05). Local newspapers were concerned with Tromsø's place on the map, and lack of support from the Norwegian government. ${ }^{16}$ An extravagant attack on 'the old story' of small town insignificance, the concert stories spoke of global changes and Tromsø's contribution to world history.

\footnotetext{
${ }^{16}$ Providing further fuel to this interpretation, Prime Minister Kjell Magne Bondevik - after so far having opposed the concert - entered the concert stage, ignored audience booing, praised the arrangement, and promised governmental funding for a research program on HIV/AIDS.
} 


\section{The Magic of Mandela}

How, then, did newspapers explain this extraordinary turn of events - the making of a success from a project doomed to failure? What I in the following section refer to as 'place spirit' partly answers this question; this was the work of local enthusiasm and place potential, of what several contributors called 'arctic magic'. Equally important, however, was the presence of Mandela and the magic created by him. A Tromsø editorial titled 'The magic of Mandela' refers to his 'magical speech' and 'magical transformation' - how, after ending his speech, Mandela was once again 'transformed as through magic' to an old, tired man. Nordlys referred to 'moments of magic' during Mandela's speech at the concert, citing also a British Independent Online claim of 'Norway touched by Madiba-magic' (Nordlys 13.06.05). And the silence during Mandela's speech was not only total, but 'devout', with the hair on 18000 necks reported to have risen uniformly (Amundsen, Nordlys 13.06.05).

The 'magic of Mandela' works in different directions. Most striking is his ability to change his audiences - grant them power, create solidarity, and make them good, both to each other and to the world. A particularly telling image of such visions, an editorial by Hans $\mathrm{Kr}$. Amundsen describes the concert departure of 18000 people, walking 'in a powerful, kind and reflective procession out from the "dump", over the bridge and towards the sun'. This was on one level a literal description; the concert was arranged at a former garbage dump, to locals known as 'the dump'; the bridge connecting the concert area with the island of Tromsø was closed during the concert, thus forcing people to walk; and crossing the bridge they were facing the midnight sun. However, references to the 'dump', 'bridge' and 'sun' may also be read as a symbolic expression, summarizing the consequences of Mandela's magic - the bridging of 'before and after', and the brightness of future goals.

In this as in the former examples given, Mandela transcends the level of political statesmanship. An unusually clear example of this tendency, a chronicle by Svenn A. Nielsen relates the 'magic of the concert' to the presence of 'the greatest human being ever to visit the city' (Nordlys 21.06.05). When, as he put it:

[W]ith an inner power similar to no other human being in the world he called us all Africans, only Jesus appearing in Tromsdalen could have been bigger. I remember thinking; why does it have to be 2000 years between every time the earth manages to produce a human being of such calibre. (Nordlys 21.06.05.) 
This is the description of a holy man, a divine human being, a Christ figure or a combination of the three. ${ }^{17}$ And Tromsø is his chosen people; they are a people changed by his presence, as 'Africans' included in his 'family', and - as 46664 ambassadors - disciples of his cause.

Further developing this theme, sacred symbolism tended to cluster around Mandela's speech, thus indicating the entrance of a liminal stage. Also some of the newspaper comments pointed in the direction of communitas, the temporary dissolution of distinctions typical of ritual liminality. ${ }^{18}$ As Hans Kr. Amundsen put it regarding the atmosphere during Mandela's speech: 'Suddenly there was not much difference between small and large, between crown princess Mette Marit and Jørgen Hattemaker ${ }^{19 \prime}$ (Nordlys 13.06.05). Interestingly, Amundsen uses as example the crown princess, rather than Mandela. Inter-structural time is not bereft of order or distinctions. Paralleling the dissolution of most distinctions, the remaining ones are further highlighted; in this case the distinction between Mandela and the crowd, the leader of the ritual and ritual novices.

\section{Place Spirit}

In an editorial titled 'Thank you Madiba', Lasse Jangås speaks of Mandela's gift to Tromsø, namely the opportunity to do something for others, to engage in acts of solidarity, and to prove commitment to a common cause. The potential for such engagements was already there, however. Integral to what Jangås refers to as 'the Tromsø-spirit', is the ability to perceive opportunities and do something about them: 'The run up for the concert has revealed the unique potential for commitment inhabiting people up here.' (Nordlys 9.06.05, 47.)

Along with the more frequently employed 'arctic magic', 20 'place spirit' refers to uniqueness and potential. These categories tend, moreover, to blend the uniqueness of place and inhabitants, presenting people as created by the landscapes surrounding them. Such linking of place and people is typical

\footnotetext{
${ }^{17}$ Descriptions of Mandela as a divine figure are not unique to the case of Tromsø. Upon Mandela's release from prison in 1990, Reverend Jesse Jackson described him as 'a Christ-like figure' who had 'suffered his way into power', adding that 'now that the stone has been rolled away' the world beheld an apocalyptic 'second coming'. During a visit to the US later that year, Mandela was publicly hailed as 'the most sainted man of our times', as a modern day Moses (according to the then New York Mayor), as an African pope (according to Reverend Jim Holley, pastor of The Little Rock Baptist Church), and according to Time magazine 'a hero, a man, like those described by author Joseph Campbell, who has emerged from a symbolic grave reborn, made great and filled with creative power'. (Chidester 1995, 291.)

${ }^{18}$ For a description of ritual liminality, see Turner 1979.

19 'Jørgen Hattemaker' is in Norwegian a set way of referring to 'ordinary people'.

20 'Arctic magic' was a key concept both in the Olympic proposal and in connection with the Mandela concert. Indicative of this position, 'arctic magic' is included in the headline of the first chapter of the proposal, as well as in the concert heading (46664 Arctic).
} 
of primitivism in general and appears to be solidly grounded in northern Norwegian identity discourse. As sociologist Willy Guneriussen puts it in a comment on the Olympic Games proposal:

Descriptions of northern Norwegian nature have played an important role. This is a unique nature which will attract attention worldwide. It is harsh, beautiful and wild - like the northern Norwegian himself. There are steep mountains rising from deep fjords. There is 'arctic' wilderness meeting the wild and open ocean. There is winter light and midnight sun. And all this exceptional nature is close to the city - according to some statements one might get the impression that the magical, arctic wilderness more or less starts outside of the city centre cafes and crossroads. (Guneriussen 2005.)

Perceptions of the concert as a 'wild idea' belong to this perspective, as does the 'against all odds' motive and the stubborn willpower of local organizers. On the night of the concert even the weather adjusted to the enthusiasm of locals. After weeks of heavy rain, the concert revealed Troms $\emptyset^{\prime}$ s most glorious side - to locals and to the world. ${ }^{21}$ This, then, was a display of place uniqueness. With the world watching, it was an instance of a 'showing of a doing', rather than merely doing and demonstrating (Schechner 1977, 65). And with even the weather cooperating, the beloved landscapes of Tromsø emerged even grander, even more beautiful and even more spectacular.

Adding to the reservoir of 'arctic magic' the twin-themes of 'periphery' and 'smallness' figured prominently in newspaper coverage of the concert. In an editorial titled 'The world became a little bit smaller', Lasse Jangås notes that 50 countries had bought television rights to the concert, and, he continues:

[W] hat do people get to see in these countries? A small town near the North Pole, which has thrown itself into Mandela's fight, a place where the sun never sets, where people join to care for others, and where fellowship is so strong that even bad weather must give in when people want it enough. Hopefully they will understand why the fight is so important, and that it is possible for them to do what little Tromsø managed on Saturday. (Nordlys 13.06.05, 55.)

\footnotetext{
${ }^{21}$ As Yngve Nilsen put it in a commentary on TV coverage: 'Some times reality is enough, and some times television has the opportunity to convey impressions no one else can match. It was fantastic to watch Nelson Mandela greet 17000 people. The sun was shining from a clear sky. Grounds and mountain sides were green. There were white mountain tops, and there was the powerful nature of the city as stage set for one of the most important statesmen of modern times.' (Tromsø 13.06.05.)
} 
In order to make sense of this celebration of smallness and location, we need to relate it to the broader setting of mega events, as well as to contemporary currents of romantic primitivism.

Emphasis on smallness and periphery speak to the mega event genre and the importance of uniqueness. Contrasting the more typical setting of mega events, the uniqueness of this one was partly related to size and setting - to the fact of being a small town, near the North Pole. In addition, concepts of periphery appear to transcend the level of mundane geography. This periphery is also a symbolic space, constructed in response and reaction to changes in the world system. During the twentieth century, sociologists John Urry and Phil Macnaghten have argued, 'the division between nature and society increasingly came to take a spatial form, with society in and at the centre and nature as the "other" pushed out to the margins' (Macnaghten \& Urry 1998, 14). To be defined as 'nature' was to 'be defined as passive, as non-agent and non-subject, as the "environment" or invisible background conditions against which the "foreground" achievements of reason or culture [...] take place' (V. Plumwood, cited in ibid., 15).

From this perspective 'arctic' is both an extreme type of nature and an archetypical nature - 'more natural' than the rest of Norway and core places of the global geography. And in the 21st century this position has been recast as an opportunity for uniqueness - as a resource to be employed 'by the other' as images of itself. Nature, first, has emerged as a counter-structural symbol, signifying opposition to the homogenizing forces of globalisation (Beyer 1998). From this perspective, to be 'natural' is to be particular and unique - to be able to withstand the standardization of technology and modernization. Second, both nature and periphery connote truth and authenticity. As sociologist Kevin Hetherington has argued in regard to new social movements, truth and authenticity are related to all that which stand outside of the establishment - to all that which dominant culture has rejected, suppressed or displaced (Hetherington 1998)..22

Margins have always been spaces of mystery and power (Douglas 1984). What is peculiar to these contemporary versions is the lack of a dark side to

\footnotetext{
${ }^{22}$ Historian of religion Peter Beyer, similarly, describes the celebration of margins and the marginal as a common point of so-called 'nature spiritualities' - a recent current typical of New Age religiosity, liberal Christianity and environmental movements (Beyer 1998). As he puts it: 'Nature religious currents represents themselves [...] as the forgotten or suppressed religion of the marginal, of the weak and of the oppressed. Not only does the history of the oppression of aboriginal peoples, of women, of witches, of Third World peoples and traditions not negate the validity of their religious symbols, myths and rituals; rather, as with the proletariat in Marxist thought, such marginalisation from the dominant power structures is interpreted precisely as a warrant of greater authenticity. One senses that any religious culture or symbol system that is or has been the bearer of the dominant, ruling strata, or of imperial power, is for nature religion at least somewhat suspect.' (Beyer 1998, 18-19.)
} 
such forces and qualities. Related to their merging with nature and marginality, perhaps, margins are no longer characterized by purity and danger; they appear to have been reborn as 'purely good'. Much like nature this periphery is a semi-sacred space, connoting attributes and functions traditionally connected with the sacred or transcendent. ${ }^{23}$ And like nature this potential is perceived as threatened by polluting forces from outside. This is not the romantic primitivism of Rousseau and early modern representatives, but it revolves around similar issues of dissatisfaction with the state of the world, and a longing for the simplicity and purity of 'primitive' living.

Indicative of the global importance of such potential, recent Olympic Games have tended to present indigenous people as showcases of national authenticity (Chaffer \& Smith 2000). However, as a main course - rather than exotic spices - nature and primitivism may prove problematic. International mega event organizers are concerned with place uniqueness and spectacular settings, but also with practical issues such as local organizing expertise and audience facilities. In addition, mega events need mega audiences - not only as spectators of television events - but on the ground, as part of the event.

\section{We are All Africans}

The highlight $[\ldots]$ was of course Mandela's speech to the world from the scene in Tromsø. There and then we were one world. Little Tromsø and big Mandela. (Amundsen, Nordlys 13.06.05.)

If 'arctic magic' spoke to place uniqueness, then Mandela's presence signified global connections. Mandela's magic, to stick to the language of the concert, consisted partly in the linking of place uniqueness with a broader sense of global commonality and humanitarian ideals. And rather than undermining place uniqueness, this wedding underlined the global setting of local uniqueness and the modern features of place and people.

Placed under the northern midnight sun, Mandela was the bridge between particularity and universalism. Uniquely positioned to establish such connections, Mandela not only has an extraordinary political reputation. He is, in the words of sociologist John Urry, 'a signifier of the newly emergent global order' (Urry 2003, 80). Along with the Olympic flag, rain forests and Mother Theresa, Mandela 'reflects and performs a global imagined community uniting different peoples, genders and generations' (ibid.). This is

\footnotetext{
${ }^{23}$ Several scholars have noted the 'sacred' connotations of late modern nature. See for instance Rønnow 2003, Brosius 1997, and Szerszynski 2005.
} 
not the 'bad' globalisation of cultural disneyfication and crude capitalism, but the 'good' globalisation of core modern values and a globalising civil religion. More than any other living statesman, Mandela incarnates such values, and like Tromsø's his is a voice from the margins.

This broader range of civil religious values served to frame the concert. Not only an isolated event dedicated to the fight against HIV/AIDS, the Mandela concert was also related to Tromsø's position as a city of justice, tolerance, pluralism and peace. On a general level the success of the concert was interpreted as hope for a better future and evidence that world improvement is possible - that each and one of us can make a difference. In more specific terms an editorial by Hans Kr. Amundsen presented 'justice' as the cause contributed to: 'We know that we have contributed to justice, and that we have done so together with Nelson Mandela. That is all that matters.' (Nordlys 13.06.05, 2.) Also, concepts of tolerance and pluralism figured prominently in descriptions of the event. As one commentator put it in connection with Sami musicians: 'the Mandela concert will be remembered as a concert in which expressions from widely different cultures were united' (Nordlys 13.06.05). Finally, Ole D. Mjøs found confirmation in the concert of Tromsø's position as a peace city. Tromsø should raise a statue of Mandela in the centre of the city, he claimed in an interview. This will be a way to honour Mandela, and at the same time to create a common memory, 'a memory of the peace city Troms $\varnothing$ - the city that cares, that took responsibility, and that will continue to do so' (Tromsø 18.06.05). ${ }^{24}$ Himself a representative of global peace, Mjøs is chairman of the prestigious Nobel Peace Price Committee, and in the local setting has an unsurpassed record of peace-making activity, including the peace studies and peace centre at the University of Tromsø. ${ }^{25}$ Both prophet and high priest of Tromsø's peacemaking concept, Mjøs also contributed in important ways to the Olympic proposal (as a member of its advisory board) and in connection with the Mandela concert (through lobbying).

As showcases of place uniqueness and global attitudes, planned mega events are vulnerable to local opposition. Organizers depend upon the cooperation of locals, or at least on their willingness not to go public with dissent or opposition. Images of peaceful harmony fit poorly with local conflict, and for opposition to come from minority groups is particularly

\footnotetext{
${ }^{24}$ There was a lively debate in Tromsø and Nordlys regarding both the issue of a Mandela statue and of re-naming the concert area. In the aftermath of the concert, the city council has renamed the concert area 'Mandela place'.

${ }^{25}$ A medical doctor, Mjøs has formerly been dean of the University of Tromsø, and is generally regarded as the brain behind its peace studies and peace centre (where he is currently board leader).
} 
damaging. Studies of Olympic Games have revealed the damaging effects of such conflicts, as well as organizers' efforts to silence opposition. ${ }^{26}$

In contrast to these more typical settings, opposition against the concert served mainly to support the underlying stories of place potential. Opposition from the south confirmed Tromsø's position as a neglected region, thus adding flavour to the taste of success. Meanwhile, conflict to a certain degree arose in connection with the musical status of the concert. Most people probably found the list of performers somewhat disappointing. Rumours of Bono attending did not materialize, and the celebrity factor was limited to Norwegian stars, fairly unknown African bands, and international figures from the 1980s. However, in the aftermath of the concert this aspect was ignored. Having started out as an ambiguous combination of solidarity and musical event, the concert was placed univocally along the lines of the former. And with this turn of events there was no room for conflict or opposition. To be against the concert would imply opposition to Mandela and the values which he stands for - peace, justice, equality and world improvements. In theoretical terms the concert was established as a 'discourse on goodness', presenting arguments with which hardly anyone could disagree. Discourses on goodness are characterized by their irrefutability, Jill Loga has argued:

Part of the reason why the discourse on goodness is left unchallenged, is that one as an opponent would appear as cynical, selfish or evil [...] Those speaking in the discourse, then, possess a power which is irrefutable, because one as a critic would be placed in the position of evil. Since the discourse lacks opponents, it is not communicative. (Loga 2002, 34.)

Loga adds that too much goodness may invite ridicule or charges of hypocrisy (ibid.). The presence of Mandela and the overarching issue of fighting HIV/aids partly served to neutralize such potential. But certain comments indicate uneasiness as to portrayals of local goodness. Particularly interesting in this regard, a series of articles in Nordlys presented 'guidelines for new Africans' and recipes on 'how to become good Africans'. The articles were framed in a humorous tone, and the majority of people asked for comments were ethnic Africans living in Tromsø. Contrasting the rather humble tone of Norwegian contributors, ${ }^{27}$ these celebrated the basic goodness of their host population. As Liberian-Norwegian Fabian Morris put it: ‘Mr Mandela

\footnotetext{
${ }^{26}$ See for instance Chaffer \& Smith 2000.

${ }^{27}$ Among ethnic Norwegian contributors, Chief of PR for 46664 Arctic Bjørn Erik Jensen, noted that locals should become even more inclusive to foreigners living in Tromsø, as well as learn more about Africa. Anne Marit Bjørnflaten, similarly, focussed on lessons to be learned from Africans, among these a more relaxed and positive attitude to challenges and tasks. (Nordlys 14.06.05.)
} 
made you Africans because he has seen into your hearts and have seen that you fulfil the crucial criteria - that you are good people who care about others' (Nordlys 14.06.05). ${ }^{28}$

The main focus of the series was a longer interview with Benoit Tamba, originally from Gambia, now living in Tromsø (ibid.). African culture 'is sensual, not intellectual', he claimed: 'The most important element for newly appointed Africans is to learn the rhythm in music, food, sex and life itself.' (ibid.) The concert was a success because organizers and audience dared to feel such rhythms, indicating that: 'Mandela is right, people in Tromsø are probably Africans in their hearts. Although in need of some practice.' (ibid.)

Humour is not necessarily funny. In this case it served to balance the witnessing of goodness, while at the same time underlining the informal and down to earth character of locals.

\section{Concluding Comments - Ritual Enthusiasm and Meanings of Place}

As extraordinary events, rituals are usually characterized by enthusiasm and effervescence. These occasions, as Durkheim once phrased it, allow for 'a form of grandiloquence which would be ridiculous in ordinary circumstances', whose ideas 'lose all sense of proportion and easily fall into every kind of excess' (Durkheim, in Pickering 1994, 128).

A century later, the media has become one site and vehicle of ritual effervescence. Occasions like the Mandela concert allow for a break in the more mundane world of prosaic reporting, and a concomitant turn to the world of religion - to hopes and dreams, the impossible imagined, and visions celebrated. What people say on such occasions need not 'be taken at face value, but it is often indicative of deep-seated values and commitments that are not made explicit in the course of everyday life' (Bellah 1991, 170). In line with performance theory, one might add that rituals can be more or less successful, more or less functional in the sense developed by Durkheim, more or less indicative of deep-seated values and established commitments, and more or less creative.

In civil ritual settings the need for creativity may be particularly pronounced. Due to their lack of established authority structures, civil rituals must in some way strike a chord with its loosely gathered congregation. The Mandela concert managed to do this. And its success may be related

\footnotetext{
${ }^{28}$ Grace Udomba, originally from Nigeria, now living in Tromsø, in a similar vein noted that '[w] hen Mandela made you Africans, he made us brothers and sisters. It was meant as a compliment to you, for the most important asset for a good African is compassion and the ability to help those in need.' (Nordlys 14.06.05.)
} 
to at least four different ingredients. First, the concert spoke explicitly to an ongoing discourse on place identity, revolving around the need for new, more worthy and relevant images. Second, it tapped into the unfulfilled visions established by the Olympic Game committee. Third, it offered a ritual setting for displaying and experiencing the stories proposed. And fourth the presence of Mandela provided an opportunity for surpassing the national - for gaining a place on the world map and linking on to the good globalisation of core modern values.

\section{Bibliography}

\section{Bell, Catherine}

1997 Ritual: Perspectives and Dimensions. New York: Oxford University Press.

\section{Bellah, Robert N.}

1967 Civil Religion in America. - Daedalus 96 (1), 1-21.

1991 Beyond Belief: Essays on Religion in a Post-traditional World. Berkeley: University of California Press.

\section{Beyer, Peter}

1994 Religion and Globalization. London: Sage Publications.

1998 Globalization and the Religion of Nature. - Pearson, J. et al., (eds), Nature Religion Today: Paganism in the Modern World, 11-21. Edinburgh: Edinburgh University Press.

\section{Boer, Roland}

1997 Iconic Death and the Question of Civil Religion. - Re:Public (ed.), Planet Diana. Cultural Studies and Global Mourning, 81-86. Sidney: The Lilyfield Group.

\section{Brosius, J. P.}

1997 Endangered Forests, Endangered People: Environmentalist Representations of Indigenous Knowledge. - Human Ecology 25 (1), 47-69.

\section{Chaffer, Kay \& Sidonie, Smith (eds)}

2000 The Olympics at the Millennium. Power, Politics and the Games. New Brunswick: Rutgers University Press.

\section{Chidester, David}

1995 A Big Wind Blew up During the Night. America as Sacred Space in South Africa. - David Chidester \& Edward T. Linenthal (eds), American Sacred Space, 262-312. Bloomington: Indiana University Press. 
Dagbladet

26.4.2005

\section{Douglas, Mary}

1984 Purity and Danger: An Analysis of the Concepts of Pollution and Taboo. London: Ark Paperbacks.

Drivenes, Einar Arne \& Marit Anne Hauan \& Helge Wold (eds)

1994 Nordnorsk kulturhistorie. Det gjenstridige landet. Oslo: Gyldendal.

\section{Fairclough, Norman}

2003 Analysing Discourse: Textual Analysis for Social Research. London: Routledge.

\section{Geertz, Armin W.}

2004 Can We Move Beyond Primitivism? On Recovering the Indigenes of Indigenous Religions in the Academic Study of Religion. - Jacob K. Olupona (ed.), Beyond Primitivism: Indigenous Religious Traditions and Modernity, 37-70. New York: Routledge.

\section{Guneriussen, Willy}

2005 Vilt, vakkert, spektakulært og magisk! O L i Tromsø som nordnorsk identitetsprosjekt. Unpublished paper.

\section{Hetherington, Kevin}

1998 Expressions of Identity. London: Sage Publications.

\section{Laclau, Ernesto \& Chantal Mouffe}

1985 Hegemony and Socialist Strategy: Towards a Radical Democratic Politics. London: Verso.

\section{Loga, Jill M.}

2002 Godhetens makt i den politiske offentlighet. - Kvinneforskning 26, 32-40.

\section{Macnaghten, Phil \& John Urry}

1998 Contested Natures. London: Sage Publications.

Nordlys

9.6.2005; 13.6.2005; 14.6.2005; 16.6.2005; 18.6.2005; 21.6.2005

Paulgaard, Gry

2006 (in press) Identitetskonstruksjoner - hvor langt rekker de? - Tidsskrift for Ungdomsforskning.

Pickering, W.S.F. (ed.)

1994 Emile Durkheim on Religion. Georgia: Scholars Press. 


\section{Rappaport, Roy}

1999 Ritual and Religion in the Making of Humanity. Cambridge: Cambridge University Press.

\section{Roche, Maurice}

2000 Mega-Events and Modernity: Olympics and Expos in the Growth of Global Culture. London: Routledge.

\section{Rønnow, Tarjei}

2003 Moder jord: Et moderne nøkkelsymbol. - Din. Tidsskrift for religion og kultur 2, 34-44.

\section{Schechner, Richard}

1977 Essays on Performance Theory 1970-1976. New York: Drama Book Specialists.

\section{Szerszynski, Bronislaw}

2005 Nature, Technology and the Sacred. Oxford: Blackwell Publishing.

Tromsø

13.6.2005; 18.6.2005

Tromsø 2014

Faktaark, http://www.tromso2014.no (The official Internet pages of the Olympic Games proposal).

\section{Turner, Victor}

1979 Betwixt and Between: The Liminal Period in Rites de Passage. - William A. Lessa \& Evon Z. Vogt (eds), Reader in Comparative Religion: An Anthropological Approach, 234-243. New York: Harper Collins Publishers.

\section{Urry, John}

2003 Global Complexity. Cambridge: Polity Press. 
